УДК 347.1(7/8), ББК 67.404.022, ГРНТИ 10.27, КОД ВАК 12.00.03

М. Е. Маргольф, Ю. В. Холоденко

Барнаул, Россия

\title{
ЗАЩИТА ЧЕСТИ, ДОСТОИНСТВА И ДЕЛОВОЙ РЕПУТАЦИИ ПО АМЕРИКАНСКОМУ ПРАВУ
}

В статье приведено обоснование необходимости дальнейтего реформирования института защиты деловой репутащии. Актуальность темы защчтты деловой репутации обусловлена рядом факторов. Во-первых, это постоянно меняющаяся практика. Так Верховный суд РФ в обзоре судебной практики за первый квартал 2017 года указал, что для возмещения репутационного ущерба необходимо доказывать деликатный состав. Вовторых, российскому институту диффамационного права присущии следующие проблемы, обозначенные Европейским судом по правам человека: законы о диффамации терпят неудачу при попытке придать достаточный вес праву на свободу слова; даже если содержание этих законов являются удовлетворительными, практика их применения часто не в состоянии уделить должное внимание праву на свободу выражения мнения; государственные чиновники и другие лища иногда злоупотребляют этими законами; судебная система не всегда следует прецедентному праву Европейского суда по правам человека, касающемуся свободы выражения мнений и информаџии; средства массовой информации не всегда несут ответственность. В отномении Российской Федерации Европейский суд в ряде дел отмечал, что отечественные суды вообще не устанавливали гранииь между правом на свободу слова и деловую репутаџию. Наиболее разработанным на сегоднямний день считается американский институт защиты от диффамации. Многие положения, разработанные американской юрисдикцией, восприняты Европейским судом. Все вышеизложенное, а также значимость тех конституциионных прав, о которых идет речь, подтверждает необходимость тщзательного изучения зарубежного опыта, а также внесения корректировок в существующие нормы и судебную практику. 
Ключевые слова: защуита деловой репутащчии; условия правовой защцить; американское право.

Сведения об авторе: Юрий Витальевич Холоденко, кандидат юридических наук, дочент кафедры гражданского права Алтайского государственного университета. 656049, Барнаул, пр-т Социалистический, 68. E-mail: holodenko@de-kons.ru.

Сведения об авторе: Маргарита Евгеньевна Маргольф, магистрант Алтайского государственного университета. 656049, Барнаул, пр-m Социалистический, 68. E-таil: margaritamargolf@yandex.ru.

\section{E. Margolf, Y. V. Kholodenko}

Barnaul, Russia

\section{PROTECTION FROM DEFAMATION UNDERTHE US LAW}

The article supports the need for further reforming the institution of protection from defamation. The acuteness of protection from defamation is determined by a number of factors. Firstly, the Supreme Court of the Russian Federation in the judicial review for the first quarter of 2017 indicated that it is necessary to prove the tortuous composition in order to compensate for reputational damages. Secondly, the Russian institution of defamation law has such problems as: defamation laws fail when trying to give sufficient weight to the right to free speech; even if the content of these laws is satisfactory, the practice of their application fails to give due attention to the right to freedom of expression; government officials and other persons abuse these laws; the judicial system does not always follow the case law of the European Court of Human Rights concerning freedom of expression and information; the media are not always liable. The European Court noted in a number of cases that domestic courts generally did not establish boundaries between the right to free speech and business reputation. Protection from defamation is considered to be the most developed in America. Many provisions developed by the American jurisdiction have been accepted by the European Court of Justice. All of the aforesaid, as well as the significance of those constitutional rights in question, confirms the need for a thorough study of foreign experience amendments to existing norms and jurisprudence.

Key words: protection of business reputation, American law.

About the author: Yury Vitalevich Kholodenko, Candidate of Juridical Sciences, Associate Professor of the Chair of civil law of Altai State University. Department of Law, Altai State University, prospect Sotsialisticheskiy, 68. Barnaul,656049.E-mail: holodenko@de-kons.ru.

About the author: Margarita Evgenevna Margolf, postgraduate of Altai State University. Department of Law, Altai State University, prospect Sotsialisticheskiy, 68. Barnaul, 656049. Email: margaritamargolf@yandex.ru. 
Американский автор Митчелл Х. Рубинштейн определяет диффамацию как ложное заявление о лице, которое подвергает его общественному презрению, насмешке, отвращению, позорит или вызывает недоброе мнение в умах благонамеренных людей и лишает это лицо дружественного восприятия в обществе [Рубинштейн 2010].

Условиями защиты от диффамации являются:

1) ложные и порочащие высказывания о фактах;

2) высказывания в отношении заявителя;

3) высказывания должны стать известны третьей стороне;

4) наличие вреда;

5) высказывание не должно подпадать под категорию привилегированного;

6) вина [Ким 2011].

В американском диффамационном праве выделяют диффамацию письменную и устную (slander or libel). В свою очередь, нарушенное право, деликт делится на две формы: диффамация устная или письменная per se, то есть порочность налицо и порочащие высказывания, которые необходимо доказать ссылками на факты.

К диффамации per se, то есть самой по себе, наиболее часто относят:

1) обвинения в совершении преступления;

2) обвинения в наличии венерического заболевания;

3) негативные высказывания о работе, профессии, торговле или бизнесе;

4) обвинения в супружеской неверности, непристойности.

Не всякое из вышеприведенных обвинений может считаться порочащим. Только «серьезные обвинения» соответствуют этому критерию. Для бизнеса и профессии исключения ограничиваются диффамацией, которая не совместима с надлежащим ведением бизнеса, торговли, профессии. Например, обвинение в пьянстве или других аморальных проступках может повлиять на священника, однако такое же обвинение в адрес предпринимателя не может затронуть его бизнес или профессию [Рубинштейн 2010]. 
В американском праве выделяют абсолютные и относительные привилегии. Право признает, что определенные заявления, хотя они и носят порочащий характер, должны быть ограждены от судебных разбирательств.

Признание относительной привилегии возникает из общественных интересов в поощрении полных и справедливых заявлений лиц, имеющих юридическую или моральную обязанность делать такие сообщения. Например, относительной привилегией защищены заявления работодателей перед сотрудниками относительно производительности, заявления профсоюзных чиновников руководству, заявления сотрудников работодателям, критикующим других сотрудников. Против такого заявления можно выдвинуть требование, однако в этом случае необходимо доказывать злой умысел.

Понятие абсолютной привилегии - древняя доктрина. В соответствии с английским общим правом абсолютная привилегия была признана средством защиты дебатов в парламенте. Понятие абсолютной привилегии было позже воплощено в конституциях штатов. В настоящее время круг заявлений, на которые распространяются абсолютные привилегии, шире. К данной категории привилегий относятся: заявления, сделанные высшими правительственными чиновниками, депутатами в ходе дебатов, во время политических передач или речи, между супругами.

В российской доктрине и практике обсуждаются такие вопросы как идентификация субъекта в информации, восприятие общественностью порочности распространенных сведений. Одно из самых известных американских дел касалось Нью-Йоркского издателя Джона Питера Зингера 1734 года. Случай Зингера создал прецедент, по которому гражданские дела о диффамации могут рассматриваться с участием присяжных, которые решают, имеется ли в публикации информация, порочащая кого-либо. Если да, то присяжные также решают насколько индивид пострадал и какую денежную компенсацию может получить [Прессман 2004]

В случае если истцом по делу является должностное лицо, общественный деятель или дело относятся к сфере общественного интереса, то требования к 
виновности ответчика выше, чем в делах между частными лицами. Для частных лиц достаточно доказать небрежность.

Так, в гражданском деле № 95-36-Р-С, рассмотренном Окружным судом штата Мэн от 31 марта 1998 года, по иску компании LEVINSKY'S против WALMART STORES суд решал вопрос о том, попадают ли распространенные сведения в сферу общественного интереса или нет. При этом наиболее полному и последовательному рассмотрению подверглись: форма распространения сведений, контекст и содержание. Заявитель оспаривал следующие фразы: (1) Портлендский магазин Levinsky’s «дрянь» и (2) когда вы звоните в магазин Levinsky’s в Портленде, «вас заставляют ждать 20 минут, или телефон вообще не берут». Первую фразу суд квалифицировал как мнение и не рассматривал в дальнейшем. Вторая фраза прозвучала в интервью, инициированном Майклом Дж. Бордманом, репортером газеты BIZ, с менеджером магазина Wal-Mart Гилбертом Олсоном. Исследуя множество факторов, таких как личные взаимоотношения Гилберта Олсона с фирмой заявителя, имеющего неудачный опыт покупок в магазине Levinsky’s, рекламную компанию Levinsky’s, построенную на сравнении цен продукции с Wal-Mart в пользу Levinsky’s, a также то, какой общественный резонанс вызвало появление Wal-Mart на рынке Америки, суд все же пришел к выводу, что в данной ситуации необходимо акцентировать внимание на содержании конкретной фразы, в которой основной акцент делается на обслуживании клиентов, а также на проблеме конкуренции двух компаний. И все эти факторы позволили суду заключить, что фраза попадает в сферу общественного интереса [Решение Окружного суда штата Мэн 1999].

Американский ученый Джеймс Х. Халм описывает три нематериальных способа защиты чести, достоинства и деловой репутации, которые, на его взгляд, не позволяют восстановить нарушенное право [Халм 1981].

Первый нематериальный способ, который был известен в США предписание редакции СМИ о запрете на публикацию выпуска, в котором 
имеется клеветническое утверждение. Однако данный способ был отменен Верховным судом как не соответствующий праву на свободу слова.

Опровержение также стоит под вопросом в американском праве, поскольку считается, что диффамация наносит необратимый ущерб и опровержение является оправданным только в том случае, если оно является немедленным и достаточным, чтобы полностью исключить влияние диффамационного заявления. Но даже если эффект возможен, то доступность этого средства полностью зависит от сотрудничества с ответчиком: по закону он не может быть принужден отказаться от своих слов. Если ответчик отказывается отозвать заявление, истец должен действовать в соответствии с традиционной процедурой возмещения убытков.

Право на ответ в американском праве также не применяется, так как наложение на издателя обязательств опубликовать ответ противоречит свободе прессы.

Таким образом, в США основным способом защиты от диффамации, позволяющим восстановить положение лица, право которого нарушено, считается возмещение убытков.

Первый вид убытков - общие убытки. Они не подлежат доказыванию и взыскиваются, когда сведения априори порочащие, так как считается, что если распространены ложные сведения, то репутация пострадала.

Специальные убытки соответствуют понятию реальный ущерб. Первоначально состав был идентичен составу договорного права (денежная потеря, вина ответчика и причинная связь). Однако позже Верховный суд указал, что для возмещения убытков необходимо привести достаточные доказательства причинения ущерба, но не требуется никаких доказательств, которые бы указывали фактический ущерб в долларах. Таким образом, необходимо доказать, что ущерб имел место.

Штрафные убытки могут быть взысканы в том случае, если доказан злой умысел распространителя сведений. 
Возмещение номинального ущерба - это получение решения о том, что распространенные сведения были ложными и порочащими.

Вышеизложенные положения необходимо подвергнуть тщательному изучению на предмет возможности использования отечественным правопорядком. На наш взгляд, ряд приведенных положений позволит добиться соблюдения баланса между правом на свободу слова и правом на защиту деловой репутации.

\section{ЛИТЕРАТУРА}

1. Решение Окружного суда штата Мэн от 31.03.1999 дело № 95-36-Р-С. Справочноправовая система. URL: http://law.justia.com/

2. Джонатан Ким. Диффамация. Сайт юридической школы Корнелл URL: http://www.lawschool.cornell.edu/

3. Прессман Стивен. Диффамация в Соединенных Штатах. URL: usa.usembassy.de/etexts/media/unfetter/press08.htm

4. Рубинштейн Митчелл X. Быстрый взгляд на Нью-Йоркское диффамационное право. URL: https://www.researchgate.net/

5. Халм Джеймс X. Вендикация репутации: альтернативы возмещению убытков. URL: http://aulawreview.com/pdfs/30/30-2/Hulme.pdf

6. Защита репутации: Информационный бюллетень Европейского суда по правам человека. Сайт Европейского суда по правам человека [Электронный ресурс]. URL: http://www.echr.coe.int/Documents/FS_Reputation_ENG.pdf

\section{REFERENCES}

1. The ruling of the District Court of Maine of 31.03.1999 case № 95-36-P-C. Legal reference system [Reshenie Okruzhnogo suda shtata Mjen ot 31.03.1999 delo № 95-36-P-C. Spravochno-pravovaja sistema]. URL: http://law.justia.com/

2. Jonathan Kim. Diffamation. The site of the law school Cornell [Diffamacija. Sajt juridicheskoj shkoly Kornell]. URL: http: //www.lawschool.cornell.edu/

3. Pressman Stephen. Diffamation in the United States [Diffamacija v Soedinennyh Shtatah]. URL: https://usa.usembassy.de/etexts/media/unfetter/press08.htm

4. Rubenstein Mitchell H. A quick look at the New York defamation law [Bystryj vzgljad na N'ju-Jorkskoe diffamacionnoe pravo. URL: https://www.researchgate.net/ 
5. Hulme James H. Vendication of reputation: alternatives to compensation of losses [Vendikacija reputacii: al'ternativy vozmeshheniju ubytkov. URL: http://aulawreview.com/pdfs/30/30-2/Hulme.pdf

6. Protection of reputation: Factsheet of the European Court of Human Rights. The site of the European Court of Human Rights [Zashhita reputacii: Informacionnyj bjulleten' Evropejskogo suda po pravam cheloveka. Sajt Evropejskogo suda po pravam cheloveka]. http://www.echr.coe.int/Documents/FS_Reputation_ENG.pdf 